\title{
PENGARUH PENAMBAHAN SPENT BLEACHING EARTH PADA MINYAK NYAMPLUNG UNTUK GEMUK LUMAS
}

\author{
Yeti Widyawati ${ }^{1)}$, Dziki ufidian ${ }^{2)}$ \\ ${ }^{1)}$ Program Studi Teknik Kimia, FakultasTeknologi Industri, Universitas Jayabaya \\ widya_w21@yahoo.co.id
}

\begin{abstract}
Has developed a formula greases with oil-based material nyamplung (Calophyllum inophyllum L.) where base oil performance and tribological performance of the nyamplung oil enhanced with the addition of thickening former pemucat ground. The aim dropping point greases product is greater than the minimum threshold standards, namely 192,50 C. formulation of oil-based greases nyamplung, is an innovation in research in the field of lubricants are committed to produce the kinds of environmentally friendly greases and renewable
\end{abstract}

Keywords: nyamplung, greas, spent bleaching eart

\begin{abstract}
ABSTRAK. Telah dikembangkan formula gemuk lumas dengan bahan dasar minyak nyamplung (Calophyllum inophyllum L.) di mana tribological performance dari minyak nyamplung tersebut ditingkatkan dengan penambahan pengental tanah pemucat bekas. Hasil uji nilai dropping point produk gemuk lumas ini didapat pada komposisi SBE : minyak nyampung (35:65) nilai NLGI 2, ini menunjukkan bahwa campuran tersebut berbentuk gemuk lumas pada umumnya. Formulasi gemuk lumas berbahan dasar minyak nyamplung, adalah suatu inovasi penelitian di bidang pelumas yang berkomitmen untuk menghasilkan jenis-jenis gemuk lumas ramah lingkungan dan terbarukan.
\end{abstract}

Kata kunci: nyamplung, gemuk lumas, tanah pemucat bekas 


\section{PENDAHULUAN}

Gemuk atau grease adalah pelumas semi padat atau cairan sangat kental, yang merupakan koloid padat-cair yang terbuat dari cairan minyak dasar (base oil) dan padatan pengental (thickening agent). Sifat semi padat ini menjadikan gemuk memiliki kemampuan khas dan berbeda dari pelumas cair, yaitu dapat menempel di dekat permukaan gesek, sehingga dapat berfungsi melumasi sekaligus menjadi penyekat (seal). Sifat semipadat tersebut menyebabkan gemuk tidak merembes keluar dari permukaan gesek dan dapat mencegah kontaminan masuk ke dalam permukaan gesek. Oleh karena itu gemuk dapat diaplikasikan pelumasan secara praktis dan ekonomis, yaitu pada sistem pelumasan yang sederhana tanpa sirkulasi (Pirro, 2001; Lansdown, 2007).

Gemuk ramah lingkungan dapat dibuat menggunakan pelumas sintetik jenis ester, misalnya trimetilolpropan, yang bersifat ramah lingkungan (Sharma et al., 2006). Gemuk bio berbasis minyak bunga matahari juga telah dikembangkan untuk aplikasi pada alat berat (Barriga dan Aranzabe, 2006).

Selain itu isu yang berkembang global dikalangan para peneliti yaitu tentang pemanfaatan limbah industri yang amat sangat banyak dihasilkan tiap tahunnya. Dengan kemampuan untuk mengolah limbah yang ada menjadi sesuatu yang dapat dimanfaatkan kembali maupun dapat digunakan oleh masyarakat, akan sangat berdampak baik pada lingkungan disekitar pabrik tersebut dan juga masyarakat disekitarnya. Salah satu limbah yang kuantitasnya besar dan selalu dihasilkan oleh pabrik pembuatan minyak goreng yaitu tanah pemucat bekas (spent bleaching earth).

Tanah pemucat bekas merupakan limbah yang di hasilkan dari proses pemucatan minyak pada industri minyak goreng. Umumnya tanah pemucat yang telah digunakan hanya dibuang dan ditumpuk di lahan terbuka. Penanganan seperti ini dapat berdampak negatif karena dapat menimbulkan bau yang tidak sedap. Dari tanah pemucat bekas ternyata masih bisa dimanfaatkan sebagai pengental dalam pembuatan grease. Tujuan dari penelitian ini adalah mendapatkan rasio terbaik tanah pemucat pemucat bekas yang ditambahkan pada minyak nyamplung untuk gemuk lumas.

\section{METODOLOGI PENELITIAN}

\section{Bahan dan Alat}

Minyak nyamplung dan tanah pemucat bekas (SBE) bekas yang di peroleh dari PT Asian Agri. Peralatan yang digunakan : tangki pencampur yang dilengkapi pengaduk dan indikator suhu, alat-alat gelas, dan lain-lain.

\section{Metode Penelitian}

\section{Preparasi SBE}

Tanah pemucat bekas dipreparasi melalui proses filtrasi.

Tanah pemucat bekas kotor

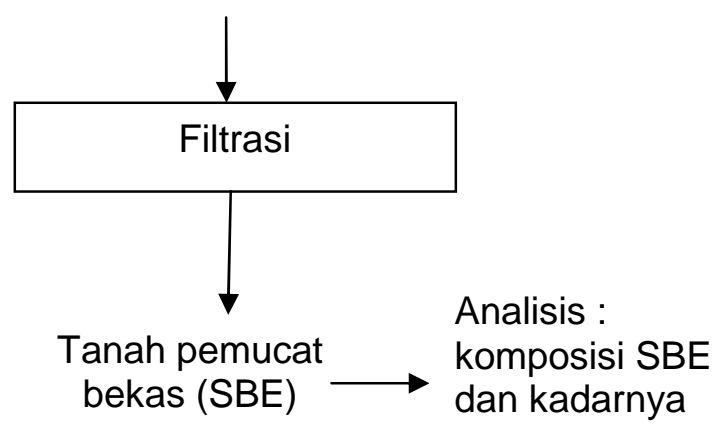

Gambar 1 Preparasi tanah pemucat bekas

\section{Peparasi Minyak Nyamplung}

Minyak nyamplung kasar dimurnikan melalui proses degumming menggunakan asam fospat $\left(\mathrm{H}_{3} \mathrm{PO}_{4}\right) \quad 20 \%$. Minyak nyamplung disaring dengan penyaring vakum. Proses pemisahan gum (degumming) dilakukan dengan cara menimbang 500 gram minyak nyamplung, lalu dipanaskan di atas hotplate sampai suhu $80^{\circ} \mathrm{C}$ sambil diaduk dengan menggunakan magnetik stirrer. Larutan asam fosfat konsentrasi $20 \%$ sebanyak 0,2-0,3\% (v/w) ditambahkan dan diaduk selama 15 menit. Minyak nyamplung dipisahkan di corong pemisah dan 
ditambahkan air hangat $\left(50-60^{\circ} \mathrm{C}\right)$ dengan cara penyemprotan. Campuran minyak dan air di corong pemisah digoyanggoyang agar air menyebar dan dapat mengikat gum dalam minyak berupa getah atau lendir

Getah atau lender terdiri dari fosfatida, protein, residu, karbohidrat dan resin. Air yang disemprotkan ke dalam corong pemisah dilakukan hingga air buangan netral (sampai pH 6,5-7). Sisa Air dalam minyak dihilangkan dengan cara memanaskan dengan hot plate pada suhu $105^{\circ} \mathrm{C}$ selama 10 menit, setelah itu dikeringkan dengan pengering vakum pada suhu $80^{\circ} \mathrm{C}$ selama 10 menit sampai tidak terdapat gelembung uap air. Diagram alir proses pemurnian minyak nyamplung dapat dilihat pada Gambar 2.

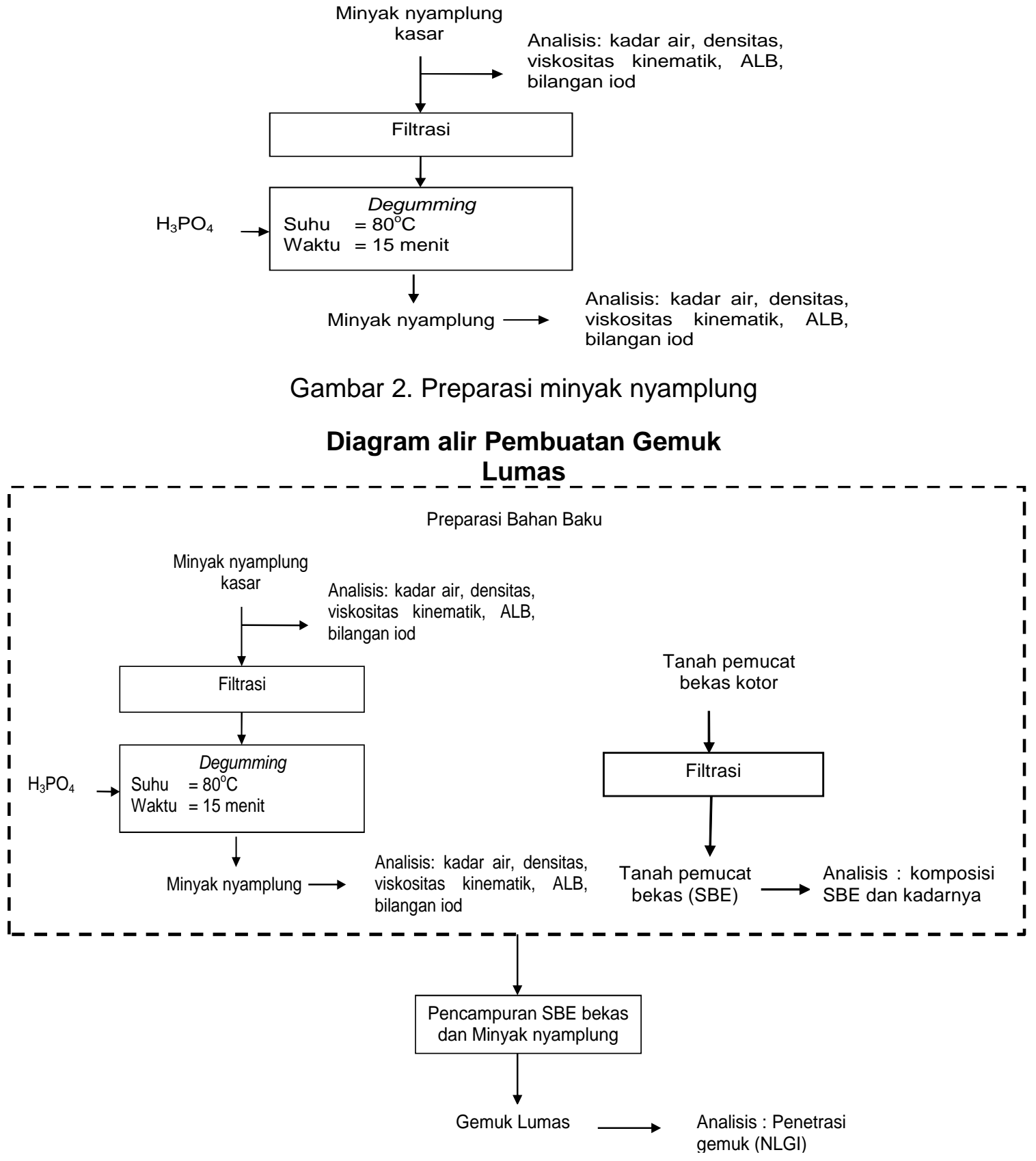

Gambar 3 Pembuatan gemuk lumas 
Formula gemuk lumas di buat dengan cara mencampur minyak nyamplung dan bahan pengental SBE dengan komposisi yang sudah ditentukan dengan spesifikasi National Lubricating Grease Institute (NLGl) pada skala 500 gram. Karakteristik gemuk lumas yang dihasilkan, diuji sifat fisika kimia dan unjuk kerjanya dengan pengujian dropping point (ASTM D566).

\section{HASIL DAN PEMBAHASAN}

\section{Analisis SBE Bekas}

Spent bleaching earth (SBE) yang digunakan merupakan limbah dari proses pemucatan (bleaching) minyak goreng di PT. Asian Agri, Jakarta Utara,umumnya penanganan limbah bekas pemucatan minyak goreng tersebut hanya dijadikan landfill atau di tumpuk.

Komposisi utama SBE adalah $\mathrm{Fe}_{2} \mathrm{O}_{3}$, $\mathrm{Al}_{2} \mathrm{O}_{3}$, dan $\mathrm{SiO}_{2}$. Dapat dilihat pada Tabel 1.

Tabel 1. Komposisi SBE bekas

\begin{tabular}{ccc}
\hline No & Komponen & Kadar \\
\hline 1 & $\mathrm{MgO}$ & $<0.07 \%$ \\
2 & $\mathrm{Al} 2 \mathrm{O} 3$ & $10.74 \%$ \\
3 & $\mathrm{SiO} 2$ & $46.01 \%$ \\
4 & $\mathrm{P} 2 \mathrm{O} 5$ & $0.66 \%$ \\
5 & $\mathrm{~K} 2 \mathrm{O}$ & $0.33 \%$ \\
6 & $\mathrm{CaO}$ & $0.84 \%$ \\
7 & $\mathrm{TiO} 2$ & $0.87 \%$ \\
8 & $\mathrm{Fe} 2 \mathrm{O} 3$ & $6.89 \%$ \\
9 & $\mathrm{~S}$ & $0.14 \%$ \\
10 & $\mathrm{Cl}$ & $0.02 \%$ \\
11 & $\mathrm{~V}$ & $106.04 \mathrm{ppm}$ \\
12 & $\mathrm{Cr}$ & $30.85 \mathrm{ppm}$ \\
13 & $\mathrm{Mn}$ & $751.50 \mathrm{ppm}$ \\
14 & $\mathrm{Co}$ & $37.53 \mathrm{ppm}$ \\
15 & $\mathrm{Ni}$ & $8.74 \mathrm{ppm}$ \\
16 & $\mathrm{Cu}$ & $23.52 \mathrm{ppm}$ \\
17 & $\mathrm{Zn}$ & $97.17 \mathrm{ppm}$ \\
18 & $\mathrm{As}$ & $2.83 \mathrm{ppm}$ \\
19 & $\mathrm{Cd}$ & $<1.67 \mathrm{ppm}$ \\
20 & $\mathrm{Hg}$ & $19.54 \mathrm{ppm}$ \\
21 & $\mathrm{Tl}$ & $3.73 \mathrm{ppm}$ \\
22 & $\mathrm{~Pb}$ & $20.18 \mathrm{ppm}$ \\
\hline
\end{tabular}

Tabel 1 memperlihatkan kandungan $\mathrm{Fe}_{2} \mathrm{O}_{3}$ SBE murni yang belum dipakai adalah 2$10 \%$ sedangkan kandungan $\mathrm{Fe}_{2} \mathrm{O}_{3}$ dari SBE bekas adalah 6-7\% ; demikian juga
$\mathrm{Al}_{2} \mathrm{O}_{3}$, sebelum $5-20 \%$ dan setelahnya 10$11 \%$ dan $\mathrm{SiO}_{2}$ sebelum $55-80 \%$ dan setelahnya yaitu $46 \%$. Salah satu komponen yang sangat berpengaruh dalam proses pengentalan untuk membuat gemuk lumas adalah $\mathrm{SiO}_{2}$ yang diketahui berdasarkan analisa XEPOX didapat kadar yang masih tinggi yaitu sekitar $46 \%$.

\section{Analisis Minyak Nyamplung}

Karakterisasi pendahuluan pada minyak nyamplung bertujuan untuk mengetahui karakteristik minyak nyamplung yang akan dijadikan metil ester sebagai bahan baku pembuatan trimetilolpropana ester. Hasil analisa sifat fisiko kimia minyak nyamplung dapat dilihat pada Tabel 2 .

Tabel 2 Sifat fisik minyak nyamplung

\begin{tabular}{lccc}
\hline \multicolumn{1}{c}{ Parameter } & Satuan & $\begin{array}{c}\text { Sebelum } \\
\text { degumming } \\
\text { (Crude oil) }\end{array}$ & $\begin{array}{c}\text { Sesudah } \\
\text { degumming } \\
\text { (Refined oil) }\end{array}$ \\
\hline Kadar air & $\%$ & 0,201 & 0,362 \\
Densitas 20 & $\mathrm{g} / \mathrm{ml}$ & 0,944 & 0,935 \\
Viskositas kinematik 40 $\mathrm{C}$ & $\mathrm{CSt}$ & 28,78 & 25,35 \\
Kadar asam lemak bebas & $\%$ & 21,03 & 19,70 \\
Bilangan asam & $\mathrm{mg} \mathrm{KOH/g}$ & 41,84 & 39,20 \\
Bilangan penyabunan & $\mathrm{mg} \mathrm{KOH/g}$ & 198,1 & 194,7 \\
Bilangan iod & $\mathrm{mg} / \mathrm{g}$ & 86,42 & 85,04 \\
\hline
\end{tabular}

Hasil analisis sifat fisiko kimia minyak nyamplung diperoleh kadar air sebesar $0,201 \%$ (b/b). Nilai ini lebih rendah dibandingkan hasil penelitian Sahirman (2009) yaitu $0,25 \%$ (b/b). Perbedaan tersebut dapat disebabkan oleh perbedaan penanganan pasca panen, seperti proses pengeringan. Pengeringan yang tepat akan menentukan rendemen minyak yang dihasilkan. Kadar air merupakan salah satu parameter penting dalam menentukan kualitas minyak nyamplung. Kadar air yang tinggi memungkinkan terjadinya reaksi hidrolisis trigliserida menjadi asam lemak bebas dan gliserol. Densitas minyak nyamplung pada suhu $20^{\circ} \mathrm{C}$ sebesar $0,944 \mathrm{~g} / \mathrm{ml}$. Densitas minyak dipengaruhi oleh bobot molekul asam lemak. Semakin tinggi bobot molekul asam lemak maka densitas semakin tinggi. Bilangan asam minyak nyamplung awal adalah $41,84 \mathrm{mg} \mathrm{KOH} / \mathrm{g}$ minyak, nilai ini lebih rendah dibandingkan hasil penelitian Sahirman (2009) yaitu 
$59,94 \mathrm{mg} \mathrm{KOH} / \mathrm{g}$ minyak. Hal ini disebabkan karena kandungan air dalam minyak nyamplung dapat menghidrolisis trigiserida sehingga bilangan asam tinggi.

Bilangan asam menunjukkan jumlah asam lemak yang terdapat dalam minyak. Kandungan asam lemak tidak jenuh dalam minyak nyamplung semakin tinggi akan memungkinkan terjadinya oksidasi pada ikatan rangkap, sehingga bilangan asam meningkat. Kondisi penyimpanan yang kontak langsung dengan udara dan besi juga dapat menjadi penyebab reaksi oksidasi yang menghasilkan asam-asam lemak berantai pendek. Nilai viskositas kinematik minyak nyamplung awal sebesar 28,78 cSt lebih rendah dari hasil penelitian Sahirman (2009) yaitu 60,96 cSt. Nilai ini masih cukup tinggi apabila digunakan sebagai bahan bakar (biodiesel).

Analisis sifat fisiko kimia juga dilakukan pada minyak hasil degumming. Pada penelitian ini, degumming dilakukan pada suhu $80^{\circ} \mathrm{C}$ menggunakan asam fosfat teknis sebanyak $0,3 \%$ (b/b). Koagulasi gum lebih cepat terjadi pada suhu $80^{\circ} \mathrm{C}$ karena penggumpalan protein terjadi pada suhu tinggi sehingga fungsi emulsifiernya hilang. Setelah proses degumming warna minyak mengalami perubahan dari warna hijau kehitaman menjadi kuning kemerahan. Hal ini disebabkan pigmen warna dominan pada minyak yaitu klorofil mengalami kerusakan saat proses digantikan dengan pigmen karotenoid yang berwarna kuning kemerahan. Gum (getah dan lendir) yang menyebabkan kekentalan pada minyak nyamplung hilang saat proses degumming, sehingga bilangan asam dan viskositas minyak turun menjadi $39,20 \mathrm{mg} \mathrm{KOH} / \mathrm{g}$ minyak dan 25,35 cSt. Kadar air mengalami peningkatan dari 0,201\% menjadi 0,362\%, hal ini dapat disebabkan masih ada air yang tertinggal setelah proses pencucian.

Minyak nabati yang memiliki bilangan iod 50 - 130 dapat digunakan sebagai fluida hidraulik. Bilangan iod dibawah 50 , nilai pour point tinggi karena kekurangan ketidakjenuhan, dan minyak nabati dengan bilangan iod di atas 130 cenderung tidak stabil karena mudah teroksidasi. Dari Tabel 2 memperlihatkan bahwa minyak nyamplung dengan bilangan iod 82-98 pour point-nya rendah. Asam lemak pada minyak nabati memiliki sifat polar dan cenderung lebih efektif melekat pada permukaan logam dibandingkan dengan minyak mineral.

\section{Analsis Gemuk Lumas}

Berdasarkan data-data analisis minyak nyamplung dan SBE, terutama data viskositasnya, maka dibuat percobaan perbandingan untuk pembuatan gemuk lumas dengan perbandingan SBE : minyak nyamplung sebesar ; 75:25, 65:35, 55:45, 45:55, dan 35:65, dan dilakukan pencampuran pada suhu kamar $\left(28^{\circ} \mathrm{C}\right)$.

Tabel 3 Penetrasi Gemuk Lumas pada suhu $28^{\circ} \mathrm{C}$

\begin{tabular}{|c|c|c|c|c|c|}
\hline \multicolumn{2}{|c|}{ Komposisi (\%) } & \multirow{2}{*}{\multicolumn{3}{|c|}{ Penetrasi }} & \multirow[b]{2}{*}{$\mathrm{NLGl}$} \\
\hline SBE & $\begin{array}{c}\text { Minyak } \\
\text { Nyamplung }\end{array}$ & & & & \\
\hline 75 & 25 & 110 & 127 & 151 & $5-6$ \\
\hline 65 & 35 & 150 & 166 & 172 & $4-5$ \\
\hline 55 & 45 & 221 & 218 & 251 & $3-4$ \\
\hline 45 & 55 & 249 & 264 & 270 & $2-3$ \\
\hline 35 & 65 & 297 & 283 & 272 & 2 \\
\hline
\end{tabular}

Tabel 3 memperlihatkan hasil formulasi antara SBE dan minyak nyamplung. Pada komposisi SBE : minyak nyampung (75:25) dan (65:35) didapatkan nilai NLGI 5-6 dan 4-5, ini menunjukkan bahwa campuran tersebut berbentuk sangat padat, Pada komposisi SBE : minyak nyampung $(55: 45)$ didapatkan nilai NLGI 3-4, ini menunjukkan bahwa campuran tersebut berbentuk sangat kental, Pada komposisi SBE : minyak nyampung (45:55) didapatkan nilai NLGI 2-3, ini menunjukkan bahwa campuran tersebut berbentuk kental, Pada komposisi SBE : minyak nyampung (35:65) didapatkan nilai NLGI 2, ini menunjukkan bahwa campuran tersebut berbentuk gemuk lumas pada umumnya. 
Tabel 4 Hasil Penetrasi Gemuk Lumas pada suhu $60^{\circ} \mathrm{C}$

\begin{tabular}{cccccc}
\hline \multicolumn{2}{c}{ Komposisi } & & Pensi & & NLG \\
\cline { 1 - 2 } SBE & $\begin{array}{c}\text { Minyak } \\
\text { Nyamplung }\end{array}$ & & Penetrasi & & \\
\hline 75 & 25 & 103 & 135 & 141 & $5-6$ \\
65 & 35 & 168 & 178 & 156 & $4-5$ \\
55 & 45 & 207 & 233 & 211 & $3-4$ \\
45 & 55 & 221 & 230 & 265 & 3 \\
35 & 65 & 280 & 263 & 288 & 2 \\
\hline
\end{tabular}

Tabel 4 memperlihatkan Hasil yang didapatkan terhadap tiap formulasi adalah sebagai berikut : Pada komposisi SBE : minyak nyampung $(75: 25)$ didapatkan nilai NLGI 5-6, ini menunjukkan bahwa campuran tersebut berbentuk sangat padat. Pada komposisi SBE : minyak nyampung $(65: 35)$ didapatkan nilai NLGI 4-5, ini menunjukkan bahwa campuran tersebut berbentuk padat. Pada komposisi SBE : minyak nyampung (55:45) didapatkan nilai NLGI 3-4, ini menunjukkan bahwa campuran tersebut berbentuk sangat kental. Pada komposisi SBE : minyak nyampung (45:55) didapatkan nilai NLGI 3, ini menunjukkan bahwa campuran tersebut berbentuk kental.

\section{KESIMPULAN}

Formula gemuk lumas berbahan dasar minyak nyamplung pada skala produksi laboratorium sebesar 20.000 gram, sudah memenuhi karakteristik gemuk lumas sesuai SNI 7069.15:2008.

Keunggulan gemuk lumas dengan bahan dasar minyak nyamplung dan bahan pengental SBE, dapat melumasi permukaan logam, karena minyak nyamplung memiliki gugus polar, hal ini terlihat dari nilai dropping point.

Formulasi gemuk lumas berbahan dasar minyak nyamplung, merupakan penelitian di bidang pelumas yang berkomitmen dapat menghasilkan jenis-jenis gemuk lumas ramah lingkungan dan terbarukan.

\section{DAFTAR PUSTAKA}

ASTM D 217, 2007, Standard Test Method for Cone Penetration of Lubricating Grease. ASTM D 566, 2007, Standard Test Method for Dropping Point of Lubricating Grease.

Barriga J and Aranzabe. (2006). Sunflower Based Grease For Heavy Duty Applications. Mecânica Experimental, $13: 129-133$.

Kilham C. 2004. Oil of Tamanu (Calophyllum inophyllum L.). http://www.newchapter.info.[12 Februari 2010].

Lansdown A.R. (2007). Lubrication and Lubricant Selection, A Practical Guide, Third Edition, London: Professional Engineering Publishing Limited.

Pirro. (2001). Lubrication Fundamentals. New York: Marcel Dekker.

Sharma B.K., Adhvaryu A., Perez J.M., Erhan S.Z. (2006). Biobased grease with improved oxidation performance for industrial application, Journal of Agricultural and Food Chemistry. 54:7594-7599. 